\title{
American Chemical Society
}

\author{
Continuation Application \\ Grant Number DE-FG01-90CE90043
}

DOE/Project SEED Student Scholars

Partnership

Submitted: March 11, 1994 


\section{PROGRESS REPORT, YEAR IV}

$6 / 8 / 93-6 / 7 / 94$ 
The American Chemical Society

\author{
PROJECT SEED I and II PROGRAMS \\ Los Alamos National Laboratory \\ Summer 193 Session
}

\author{
Sharon Dogruel \\ Program Coordinator
}

\title{
DISCLAIMER
}

This report was prepared as an account of work sponsored by an agency of the United States Government. Neither the United States Government nor any agency thereof, nor any of their employees, makes any warranty, express or implied, or assumes any legal liability or responsibility for the accuracy, completeness, or usefulness of any information, apparatus, product, or process disclosed, or represents that its use would not infringe privately owned rights. Reference herein to any specific commercial product, process, or service by trade name, trademark, manufacturer, or otherwise does not necessarily constitute or imply its endorsement, recommendation, or favoring by the United States Government or any agency thereof. The views and opinions of authors expressed herein do not necessarily state or reflect those of the United States Government or any agency thereof. 
Report Index

I. Program Description

II. Program Organization

III. Supplementary Educational Activities

IV. University Component

V. Program Highlights

VI. Program Attachments 


\section{DISCLAIMER}

Portions of this document may be illegible in electronic image products. Images are produced from the best available original document. 


\section{Program Description}

Project SEED is an innovative career development program sponsored by the American Chemical Society for economically disadvantaged high school students. SEED students spend ten weeks during the summer in a research laboratory working under the supervision of a professional researcher or assistant.

The primary objective of Project SEED is to encourage participants to pursue strong academic programs in order to more fully develop their career potential thereby providing a firm foundation for post secondary opportunities. The intent of both SEED I and II is not to create scientists, rather, it attempts to overcome some of the obstacles - social, institutional, attitudinal, and educational - which have traditionally excluded the economically disadvantaged from preparation for and entrance into professional careers.

The summer experience at Los Alamos is designed to involve students in meaningful research supplemented with educational activities that expose students to broader perspectives. These activities include special presentations, tours, field trips, career information, Einancial aid counseling, and communication skills development. SEED students prepare and display a poster session that highlights their work, give technical talks to their mentor's groups, and submit a brief technical summary.

This summer the University of New Mexico at Los Alamos initiated a special course for Project SEED students. The weekly sessions focused on academic skills training in anticipation of post secondary programs coupled with the development of greater self confidence through academic success and effective communication. since there were two groups of students, SEED I and II, the instruction was tailored accordingly. Students received one transferable university elective credit for their participation in the course.

\section{Program Organization}

\section{Laboratory Mentors:}

Various divisions throughout the Laboratory were contacted to recruit SEED positions. Divisions were selected that conduct appropriate projects that involve chemistry and have unclassified areas where students may be located. Potential mentors were contacted and asked to submit project descriptions that were suitable for a high school student who had completed a course in chemistry. The projects had to incorporate learning objectives and training opportunities on laboratory instrumentation. 
The project descriptions were screened and selected for the overall quality of the experience, the learning objectives involved, and the opportunities for training on specialized instrumentation. Ten Project SEED I positions were selected and Eive Project SEED II positions.

Mentors were individually contacted to discuss the specific project and insure that the program goals and objectives were well understood. This also provided time for new mentors to ask questions about the student selection process and receive additional information about successful mentoring strategies.

Student Recruitment and Selection:

Student recruitment for Project SEED I positions started in April with visits and mailings to eleven area high schools. Schools were asked to announce the visit beforehand and make arrangements for interested, qualified students to attend the presentation. Packets were left with counselors as well as faculty who volunteered to act as point-of-contact for the program. Forty two qualified applications were received for the ten slots. The applications were matched to the positions on the basis of mutual general interest and overall student qualifications. The mentors were instructed to select the student they felt best matched their position. Mentors were also instructed to choose an alternate in the event a selected student declined.

Five Project SEED II students were eligible for a second summer research experience and positions were recruited for these students. One student dropped before the program began in order to continue working with her Project SEED I mentor in another Laboratory program. Her stipend was refunded.

Schedules:

The students worked with their individual mentors for $80 \%$ of the time and spent the remaining $20 \%$ of the time attending supplementary educational activities. A schedule of these activities was distributed at the orientation session and students were advised to share the information with their mentors.

Each week, Wednesday morning was devoted to the university course and afternoons were spent attending special presentations and tours. The schedule was designed to maximize student contact with technical staff as well as peers and other students. Time was set aside for group feedback and general discussions about project work and the scientific community as a whole. 
Communications Skilis:

To assist the students prepare their poster sessions and

technical summaries, several sessions on effective communications were conducted that included topics on oral, written, and visual skilis. Most of the students indicated that they had benefitted most from the communications requirements of the program and they felt that this component will have significant impact on their future plans. Although students routinely write reports as part of their high school courses, they stated they seldom (if ever) had to give a technical talk or prepare a poster display to illustrate their accomplishments. The Project SEED experience allowed them to sharpen these skills and provided an actual product that they then could use as a professional sample of their work.

Evaluation:

In addition to the ACS Project SEED survey forms, Los Alamos administers a pre- and post-program questionnaire to determine overall program effectiveness and specific areas that may need modification. The results of the survey are summarized below:

* overall rating of the summer program

\begin{tabular}{|c|c|c|c|}
\hline LW & 1 & 2 & $\begin{array}{l}3 \\
8 \%\end{array}$ \\
\hline
\end{tabular}

* extent to which students' interests matched research assignment

$\begin{array}{ccccccc}\text { displeased } & 1 & 2 & 3 & 4 & 5 & \text { pleased } \\ & & & & & & \\ & & & 53 \% & 15 \%\end{array}$

* extent to which the university Project SEED course was valuable

$\begin{array}{llllll}\text { not at all } & 1 & 2 & 3 & 4 & 5 \\ & & 3 \% & 23 \% & 62 \%\end{array}$

* extent to which mentor and colleagues were sensitive to needs of student

$\begin{array}{llllll}\text { not at all } & 1 & 2 & 3 & 4 & 5 \text { very helpful } \\ & & & 8 \% & 92 \%\end{array}$

* extent to which Project SEED will have an impact on future

no impact $1 \quad 2 \quad \begin{array}{ccc}3 & 4 & 5 \\ 15 \% & 30 \% & 46 \%\end{array}$ significant impact 
* the likelihood of now choosing a career in science, math, or engineering

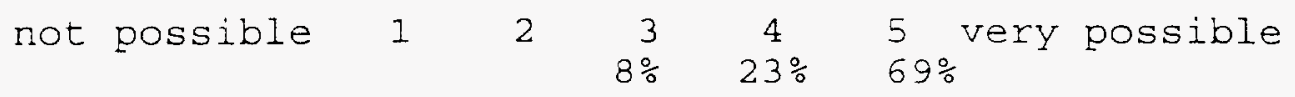

Students were also asked to complete a number of open-ended questions that asked:

What would you list as your major accomplishment working with your mentor and group?

$$
\begin{aligned}
& \text { Sample responses: "...confidence to pursue a career } \\
& \text { in science." } \\
& \text { "I learned how to solve problems" } \\
& \text { "I know I have what it takes to become } \\
& \text { an engineer" } \\
& \text { "I can do a job on my own and do it well" }
\end{aligned}
$$

What did you learn about yourself as a result of your work experience?

$$
\begin{aligned}
& \text { Sample responses: "I'm determined to learn." } \\
& \qquad \begin{aligned}
& \text { I can do a lot." } \\
& \text { "Don't feel inferior to more educated } \\
& \text { people, learn from them" } \\
& \text { "I learned to use my time wisely." }
\end{aligned}
\end{aligned}
$$

What are some important points you have learned about working with people in the workplace?

$$
\begin{aligned}
& \text { Sample response: "Ask a lot of questions." } \\
& \text { "I enjoy responsibility." } \\
& \text { "Work can be fun." } \\
& \text { "Be friendly and meet new people." }
\end{aligned}
$$

The students were asked to suggest ways to improve the program and the only significant response was to provide more opportunities for them to be together. One suggestion was to have a mid-academic year meeting during December or early January for the students to re-convene and see how the year is going. This would also allow students who had graduated and were in college to attend since they would be home during Christmas break. 
III. Supplementary Educational Activities

Throughout the summer the students spent approximately $20 \%$ of their time attending supplementary educational activities that included special presentations, tours of Laboratory facilities, demonstrations, and a university course to prepare them for their college experiences.

IV. University Component

Most Project SEED students in our area have not spent much time on a college campus nor have adequately prepared for the university experience once they arrive on campus. To better prepare the students for this experience and thus help stem the loss of qualified undergraduates, a special course was developed for the SEED students held each week on the University of New Mexico Los Alamos campus.

The university course met every wednesday morning from 8:30 a.m. until 12:00 p.m. to focus on how to prepare for college. There were special sessions on Einancial aid, how to handle university coursework, study skills, and student life. A special instructor was hired by the university to deliver the course and each student earned one university elective credit for their participation.

In addition to the course, the students were able to access the university library, career counseling services, and each completed a self-guided career information search on the computerized CIS system. The instructor scheduled a one-on-one session with each student to address their specific questions and help them prepare a sound post secondary plan.

V. Program Highlights

The poster session and reception was particularly well attended and each student received a certificate of completion. The mentors accompanied their students to receive certificates.

Each student prepared a technical summary of their work and all indicated how much they felt they had learned from their mentors and group. The groups, likewise, were proud of their student's accomplishments and most had special individual recognition events such as a group lunch for their SEED student.

At the end of the summer program several students were told by their mentors that they intended to hire them for the summer 194 Undergraduate Student Program (UGS). Several others were accepted into the Preservice Research Institute for Science and Mathematics (PRISM) program which provides a support network to assist students through their initial college programs. 
Two students were accepted into the High School Co-op program which brings seniors to the Laboratory every afternoon throughout their academic year for additional research experiences. The students receive a salary for their special employment.

Based upon the information on colleges and scholarships provided during the Wednesday university course, three students have succeeded in obtaining full college scholarships for the Eall 194 semester. Four Project SEED II students started their university program immediately upon completion of the program and each had succeeded in getting financial aid ready while they were SEED I students.

Laboratory mentors indicated they enjoyed sponsoring thastudents and most stated they would be receptive to sponsoring another SEED student in FY94. 
VI. Attachment Index

Program Announcement

Student Application Packet

Evaluation Survey

Poster Session and Reception Brochure 


\section{Project SEED: \\ Summer Educational Experience for the Disadvantaged}

\section{What is Project SEED?}

Project SEED is an innovatue career development actuity administered by the Amencan Chemical Sockety for economically disadvanlaged high school students. SEED students spend len weeks during the summer in an academic, industrial, or govemmental research laboratory working under the supervision of a researcher or research assistant. Shudents eam a small summer stipend, recetve career and college counseling. and partcipate meaningtully in research. Yet, ti 8 the personal relatonship between the students and the researcher that 8 the key lactor in rasing these students' goats and expanding thet horkons.

All administrative expenses of the program are bom by ACS. Studer stipends corne from volunteex conerbutions from individual ACS members. ACS bocal sections, corporetions, and foundutions.

\section{How Are Institutions Selected to Sponsor a SEED Student?}

Interased inswitons spply to the Amerien Chemial Sodety's Corrmitice on Proped SEED for funding a the beginning of each year. Award monis cover sudent sopends. Supples matertak, and any ovethead expenses are proulded by the particlpathn institution. Prority for funding $\&$ otven to thoer institutions with matching or supplemented funds from beal sources or ACS bed section.

\section{How Are Students Selected?}

The funded instrubons recruil their oun students to partictpate in the program. The researcher of each insarution contacts boed high schoots in order to iden ify - large number of polentally eligible students.

Snidents are selected based upon grade point average, standardized lest scores (if avaibble). and leacher recommendacons. All students must have completed the 11th grade. twe within commuting distance of the institulon, and come from an economicaly deadvantaged family. Researchers interview the moat likely candidates, boling for students who, wh encouragement and enrichment trom this progen an more fully develop the polenter.

\section{How Successful is Project SEED?}

Ova $1.500 \mathrm{high}$ sechod sudents and 200 instrartons hove partoditied in th summer sdence outresch progerm sthee th begen in 1968.

In 1979. - random merple of SEED sudents were rinued of the sudent reponding 978 hed continued thet educteon bayond hish achool $35 \%$ hed rectud depen by 1979, and 148 were in Srodute school.

SEED doas not ty to create solentba. Rather, attempts bowroome some of the obredes - sodill

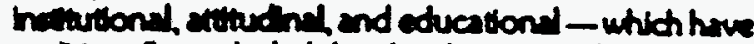
roditonaly exctuded the deadvantaged from preparation for and entrance into proferstonal careas. Cearly. Proyed SEED has been a great success tor thoe fortunale students utio have participated in this model program.

For more information, conloc: Project SEED

American Chemical Sodety

1155 Sixteenth Street N.W.

Washington, D.C 20036

(202) 872.4600 


\begin{tabular}{|c|c|c|}
\hline STUDENT & MENTOR & POSTER TITLE \\
\hline Kristin Arellano & Mike Ebingw, Ee-1E & $\begin{array}{l}\text { Acid Dissolution of } \\
\text { Synthetic (Fe, Cr) }(\mathrm{OH}) 3 \\
\text { Solids }\end{array}$ \\
\hline Somyr Barolo & Mark Hoffbouer, CLS-2 & $\begin{array}{l}\text { Surface Analysls and the } \\
\text { Celculation of Adsorbate } \\
\text { Coverages }\end{array}$ \\
\hline Carlos Chavez & $\begin{array}{l}\text { Nigal Cockroft, CLS-6 } \\
\text { SST-9 }\end{array}$ & $\begin{array}{l}\text { Laser Spectroscopy and } \\
\text { Energy Transfor in Solids }\end{array}$ \\
\hline Theresa Corrales & Konneth Salazer, CM-STC & $\begin{array}{l}\text { Superconductivity in the Pb } \\
\text { \& Sb Doped } 2223 \text { BSCCO } \\
\text { Metd Systems }\end{array}$ \\
\hline Vincent Dominguez & Caivin Martell, CLS.1 & Environmental Restoration \\
\hline Billy Huffman & Robert Walker, T-12 & $\begin{array}{l}\text { Plotting Chemical Reaction } \\
\text { Functions }\end{array}$ \\
\hline Patrick Lopez & Roger Tennant, CLS-2 & $\begin{array}{l}\text { Jet Mixing Simulations: } \\
\text { Tank 101-SY }\end{array}$ \\
\hline Lorenzo Lovato & Ben Mottes, MEE-11 & $\begin{array}{l}\text { Structuro/Property } \\
\text { Relationships in Conducting } \\
\text { Polymers }\end{array}$ \\
\hline Brian Moestes & John Coogan, CLS.6 & $\begin{array}{l}\text { Applications of Advanced } \\
\text { Oxidation/Reduction } \\
\text { Processes to Pollution } \\
\text { Control }\end{array}$ \\
\hline Danial Montoya & Jod Williams, MST-7 & $\begin{array}{l}\text { Cleaning of Oll on a Quartz } \\
\text { Crystal with the Ald of } \mathrm{CO}^{2} \\
\text { (OMC) }\end{array}$ \\
\hline
\end{tabular}

\begin{tabular}{|c|c|c|}
\hline STUDENT & MENTOR & POSTER TITLE \\
\hline Mellsea Nerenjo & Kurt SIckofus, MST-4 & $\begin{array}{l}\text { Crystal Groin Andysis of } \\
\text { Anteaxl Pottery }\end{array}$ \\
\hline Michelle Valder & Julie Wilson, LS-2 & $\begin{array}{l}\text { Molecular Biology and } \\
\text { Blochemletry: The Structure } \\
\text { and Function of Specific } \\
\text { Sequences of DNA }\end{array}$ \\
\hline Bryan Velasquez & Ed Ooodwin, LS-1 & $\begin{array}{l}\text { Radiation Induced Mitotic } \\
\text { Anomalles }\end{array}$ \\
\hline
\end{tabular}


American Chemical Society PAONECT SEED

1993

As the American Chemical Society's major commitment to social action. Project SEED was astablished in 1968 to help expand the career and educational outlook of high school students from families with incomes that meet financial program guidelines. The program is an innovative career development activity where students spend ten weeks during the summer in an academic, industrial or government research laboratory working under the supervision of a professional researcher. The primary objective of Project SEED is to encourage participants to pursue strong academic programs and to more fully develop their career potential.

The summer experience is designed to involve students in meaningful research supplemented with educational activities that include mathematics enhancement sessions, tours of selected Laboratory facilities, career and financial aid counseling for post-secondary training and oral and written communication skills development. Students prepare a technical summary, give presentations to their sponsoring groups and design and display a poster session.

This summer fourteen high school juniors and seniors from five high schools throughout northern New Mexico have successfully completed the Laboratory's fourth Project SEED session.

Individual mentors in CLS, MST, T, MEE. EES, CM-STV and LS divisions quided and supervised the students in their introduction to research at Los Alamos.

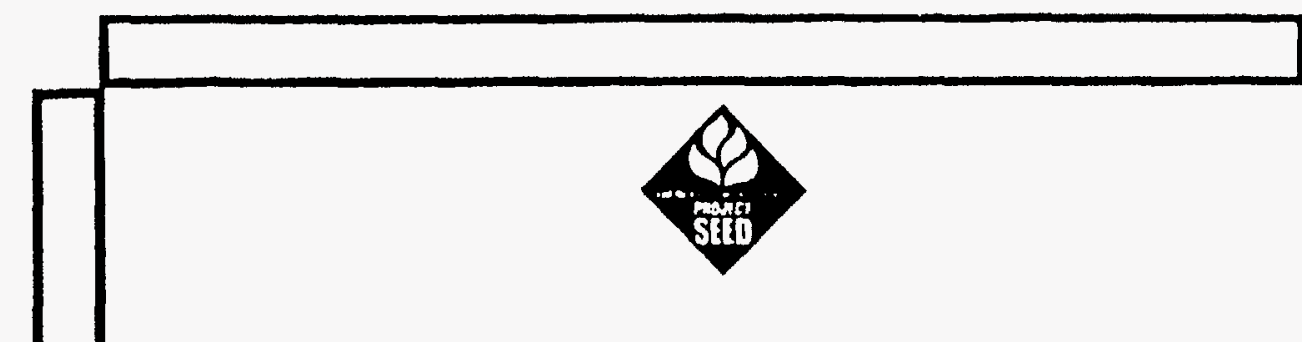

AMERICAN CHEMICAL SOCIETY

LOS ALAMOS NATIONAL LABORATORY

PROJECT SEED 1993

POSTER SESSION AND RECEPTION

FRIAAY, AUGUST 13 


\section{THE AMERICAN CHEMICAL SOCIETY \\ Project SEED II}

\section{Los Alamos National Laboratory \\ General Program Information}

Project SEED is an intensive career development activity where high school students spend ten weeks during the summer participating in meaningful scientific activities under the supervision of Laboratory research staff. The primary objective of Project SEED is to encourage participants to pursue strong academic programs and to more fully develop their career potential.

This summer high school juniors and seniors from schools throughout northern New mexico will have the opportunity to learn how scientific research is conducted at Los Alamos National Laboratory. Project SEED students become actively invoflved in a wide array of activities that contribute to major research efforts such as, learning how modern ultra-fast lasers are used to study chemcial and physical surface properties, or, how to use high-energy accelerators to treat water contaminants, as two examples.

Project SEED is designed to furthe: motivate capable students to consider professional careers. The program targets students from economically disadvantaged families who may have to overcome obstacles - social, institutional, attitudinal, and educational - to prepare and enter a professional career. Eligible students must be interested in scierice and must have completed a one year's course in chemistry.

SEED II students accepted into the program will receive a stipend of $\$ 1700$ for their participation.

In addition to their Laboratory research experience, students will participate in special activities tailored to the needs of Project SEED II students.

All Project SEED students will write a report of their summer's experience and design and display a poster session illustrating their work at the Laboratory. 


\section{U.S. DEPARTMENT OF ENERGY \\ AMERICAN CHEMICAL SOCIETY \\ LOS ALAMOS NATIONAL LABORATORY \\ PROJECT SEED II PROGRAM}

PARTICIPANTS: Former SEED I high school participants; no student who has matriculated in college is eligible.

ENROLLMENT: A limited number of positions available to students from economically disadvantaged families. Students must have completed one year of chemistry by the beginning of the program.

DURATION: $\quad 40 \mathrm{hrs} / \mathrm{wk}$ (June 7 to August 13,1993 )

LOCATION: $\quad$ Los Alamos National Laboratory

COMPENSATION: Students receive a $\$ 1700$ stipend. Students will have an opportunity to earn both high school and college credit under the concurrent enrollment agreement set up by the University of New Mexico, Los Alamos and participating area high schools.

PHILOSOPHY: $\quad$ Project SEED offers qualified students meaningful scientific activities under the supervision of Laboratory research staff. The primary objectives are

a. to encourage participants to pursue strong academic programs and to more fully develop their career potential;

b. to prepare participants for entrance into professional careers by providing students with work experience within a professional setting;

c. to encourage a more serious consideration of scientific careers;

d. to enhance each participant's self-confidence and ability to work effectively with research equipment, concepts, and scientific professionals.

Participants spend 80 percent of their time with a mentor, and 20 percent of their time participating in special activities tailored to the needs of Project SEED II students.

Contact: Huguette Sirgant, Project SEED Coordinator

Los Alamos National Laboratory, MS P278

Los Alamos, NM 87545 Phone: (505)667-1919 
If you have had courses in the following, indicate the number of semesters. If you are presently enrolled in a course, write "Now" in the space provided.

\section{Science}

General Science

Phystcal Science

Biology

Chemistry

Physics

Computer Science/s

Other
Math

Algebra I
Algebra II
Geometry
Trigonometry
Computer Math
Calculus
Other

Algebra I Algebra I Geometry Trigonometry Computer Math other

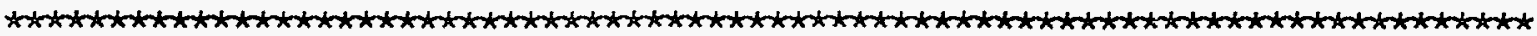

In your own words, write about yourself, your plans after high school, why you consider yourself to be a good candidate for the ACS Project SEED Program, and what personal benefits you would hope to gain if you were chosen for this program. Please answer THOUGHTFULLY and COMPLETELY. Also, indicate any special skills that you possess and 1 ist any honors or awards that you have won. Attach a separate page/s if you need additional space. 


\section{AMERICAN CHEMTCAL SOCIETY \\ Project SEED \\ Los Alamos National Laboratory \\ Educational Outreach, HRD -5, MS P278 \\ Enrollment Application}

THIS LETTER OF APPLICATION SHOULD BE ACCOMPANIED BY A LETTER OF

RECOMMENDATION FROM YOUR CHEMISTRY TEACHER. RETURN APPLICATION, LETTER OF RECOMMENDATION, TRANSCRIPT, AND ACS STUDENT FINANCIAL STATEMENT TO:

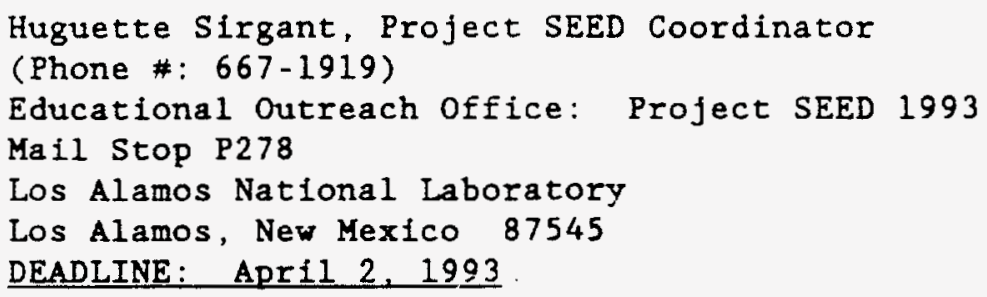

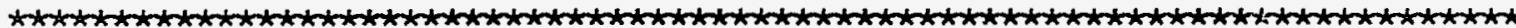
NAME :

(FIRST) (MIDDLE) (LAST)

ADDRESS :

(STREET/ROUTE/BOX)

HOME PHONE :

(CITY) EMERGENCI PHONE:

(NAME OF FATHER/GUARDIAN)

(NAME OF MOTHER/GUARDIAN)

(FATHER'S OCCUPATION)

(MOTHER'S OCCUPATION)

(SCHOOL)

$\overline{\text { (GRADE) }} \overline{\text { (BIRTHDATE) }} \overline{\text { (U.S. CITIZEN) }}$

(NAKE/S OF NEAREST RELATIVE WORRING AT LANL)*

(LOCATION/S WHERE RELATIVE WORKS)

* IF ADDITIONAL SPACE IS REQUIRED FOR MORE THAN ONE RELATIVE, USE SPACES BELOW : 
AMERICAN CHEMTCAL SOCIETT

Project SEED II

Los Alamos Kational Laboratory

Educational Outreach, HRD-5, KS P278

Enrollment Application

THIS LETTER OF APPLICATION SHOULD BE ACCOMPANIED BY A LETTER OF RECOMONDATION FROM YOUR CHEXISTRY TEACHER. RETURN APPLICATION, LETTER OF RECOMENDATION, TRANSCRIPT, AND ACS STUDENT FINANCIAL STATEMENT TO:

Huguette Sirgant, Project SEED Coordinator

(Phone \#: 667-1919)

Educational Outreach offlce: Profect SEED 1993

Ya11 Stop P278

Los Alamos National Laboratory

Los Alamos, Ney Mexico 87545

DEADLINE: Apr 11 2,1993

NAME :

$\begin{array}{lll}\text { (FIRST) (MIDDLE) } & \text { (LAST) }\end{array}$

ADDRESS :

(STREET/ROUTE/BOX)

HOKE PHONE :

(CITY)

EMERGENCY PHONE:

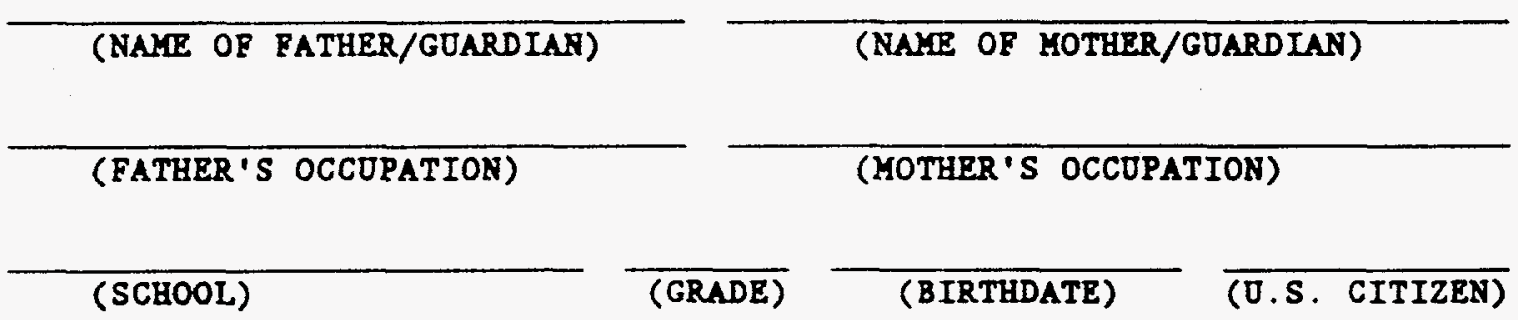

(NAYE/S OF NEAREST RELATIVE VORRING AT LANL)*

(LOCATION/S WHERE REIATIVE WORKS)

* IF ADDITIOMAL SPACE IS REQUIRED FOR MORE THAN ONE RELATIVE, USE SPACES BELON: 
If you have had courses in the following, Indicate the number of semesters. If you are presently enrolled in a course, write "Now" in the space provided.

\section{Sclence}

General Science

Physical Science

B lology

Chemistry

Physics

Computer Science/s

other

\section{Math}

Algebra I

Algebra II

Geometry

Trigonometry

Computer Math

Calculus

other

In your own words, write about yourself, your plans after high school, wh you consider yourself to be a good candidate for the ACS Project SEED II Program, and what personal benefits you would hope to gain if you were chosen for this program. To what extent, if any, has participation in SEED I Impacted your future career goals and what do you hope to achieve in SEED II?

Please answer THOUGHTFULLY and COMPLETELY. Also, indicate any special skills that you possess and 11 st any honors or awards that you have won. Attach a separate page/s if you need additional space. 
1993 AMERICAN CHEMICAL SOCIETY Project SEED

\section{STUDENT FINANCIAL STATEMENT}

Name :

(MIDDLE) (LAST)

$$
\text { (FIRST) (MIDDLE) (LAST) }
$$

Sex: (check one) Male Female Grade in Fall 1993:

Race: (check one) N___ Native American ___ Asian/Pacific Black

Hispanic White

other

Social Security Number

Tota]. Annual Famfly Income

$$
\begin{aligned}
& \text { (From latest IRS Form } 1040 \text { or other income } \\
& \text { statement) }
\end{aligned}
$$

Size of Family Unit

Do you live in a single parent household? Yes No

Has elther of your parents attended college? Yes No

I certffy that to the best of my knowledge, the information on this form is true.

(SIGNATURE OF PARENT/GOAROIAN OF APPLICANT)

I certify that I have seen the completed financial statement. 


\section{AMERICAN CHEMICAL SOCIETY \\ Project SEED \\ Pre-Program Questionnaire}

This questionnaire has been designed to gather information that will help us evaluate and imporve our program. Your answers will be anonymous, so you need not put your name on the questionnaire. Please feel free to answer the questions as honestly and thoughtfully as you can, and keep in mind there are no correct answers.

(Please circle only one answer code unless otherwise instructed.)

1. Sex:

Female $\cdot \cdot \cdot \cdot \frac{1}{2}$

2. Race:

Anglo. . . . . 1

Asian. . . . . 2

Black. . . . . 3

Hispanic . . . 4

Native American. 5

other (specify). 6

3. What do you expect to gain from the sumer ACS Project SEED program?

4. What plans do you have after high school graduation?

Attend college. . . . . . . . . . . . . . . . I

Attend vocational/technical school. . . . . 2

Get a job... . . . . . . . . . . . . . 3

other (please specify). . . . . . . . . .4

5. If you plan on attending college or a voc/tech school, list three institutions that you presently are considering?
a.
b.
c.

6. Thinking back over your junior and senior high school math and science courses, what qualities do effective 
science/math teachers possess?

7. What qualities did your least effective science and math teachers possess?

8. Do you know any adults who are professionals who have earned college degrees and are working in fields that use the knowledge and training their degree providdd?

Yes

No - - - - -

9. What area of science do you most enfoy?

whin this area, what kinds of activities do you enjoy doing?

10. Presently, what is the likelihood that you will choose a technical career (one that involves a substantial background in mathematics and science)?

None

1

2

3

4

A 1 ot

11. Rate your level of interest in the following topics: (1=low, 5=high)
a. computers
b. lasers
c. chemistry
d. physics
a. life sciences
f. problem-solving
using mathematics
g. writing/composition
h. environmental science
i. engineering

$\begin{array}{lllll}1 & 2 & 3 & 4 & 5 \\ 1 & 2 & 3 & 4 & 5 \\ 1 & 2 & 3 & 4 & 5 \\ 1 & 2 & 3 & 4 & 5 \\ 1 & 2 & 3 & 4 & 5 \\ 1 & 2 & 3 & 4 & 5 \\ 1 & 2 & 3 & 4 & 5 \\ 1 & 2 & 3 & 4 & 5 \\ 1 & 2 & 3 & 4 & 5\end{array}$


12. Do you feel that you can be ready to present your poster related to your research project and summer experiences by Friday, July 32, 199 ? Yes No

13. As best as your ability permits at this early time, describe the work your group is doing and some of your specific assignments as they relate to the group's work.

14. Please list suggestions of program topics and site tours that you would like to see incorporated into this summer's SEED programing.

15. Feel free to use the space below to list any concerns, questions or issues that you feel need to be addressed. 


\title{
Project SEED Student Evaluation
}

\author{
Summer '93
}

I hope that this summer's experience in Project SEED has been a productive one for each of you. Without doubt I have truly enjoyed working with you. Your hard work and dedication to learning new concepts and skills are to be highly commended! So that we can continue to improve all aspects of this second-year program, would you help us by answering candidly each of the following questions?

1. How would you rate your overall experience with this summer's Projet SEED program?

low $1+2 \quad 3 \quad 3 \quad 3$ high

2. To what extent were your personal interests matched with your research assignment?

$$
\text { displeased } 1{ }^{2}{ }^{2}+3{ }^{3}+{ }^{4}{ }^{5} \text { very pleased }
$$

3. Which of the tours/seminars did you find most valuable or interesting?

Why?

4. Which of the tours/seminars did you find least interesting?

Why? 
5. Were there any laboratory sites you would have liked to tour but didn't?

6. To what extent did you tind the UNM-LA Project SEED class valuable to you?

$$
\text { not at all } 1+2+3 \quad 3 \quad 5 \text { very valuable }
$$

7. To what extent did you find your mentor and colleagues sensitive to your needs and questions?

$$
\text { not at all } 1+2 \quad{ }^{2}+3 \quad 5 \text { very helpful }
$$

8. To what extent do you think Project SEED will have any impact on your future career choices?

$$
\text { no impact } 1 ـ_{2}^{2}{ }^{3}+4 \quad 5 \quad 5 \text { very significant impact }
$$

9. What do you feel is the likelihood of your choosing a career in math, science or engineering?

$$
\text { not possible } 1+2
$$

10. What did you learn about yourself as a result of your work experiences?

11. List several important points you feel that you learned about working with people in the workplace.
a.
b.
c. 
12. Other than completing the nine-week program successfully, what would you list as some of your major accomplishments related to your work with your mentor and group?

13. When considering your on-the-job skills at the beginning of the SEED program, what one area would you consider to be your greatest weakness?

14. If you had the nine weeks to repeat, what would you have done differently?

15. Give three to five valuable pieces of advice for a future SEED student.
a.
b.
c.
d.
e.

16. How could we have helped to improve your Project SEED experience? 
The American Chemical Society

\title{
DOE/Project SEED Program
}

Oak Ridge National Laboratory

Summer 1993 Session

\author{
Terry Lashley \\ Program Coordinator
}




\section{Oak Ridge National Laboratory \\ Pregram Organization}

\section{Laboratory Mentors:}

Potential mentors were contacted and asked to submit project descriptions appropriate for high school students who had completed at least one year of chemistry. Seven different divisions were represented including: Chemica! Technology, Netals and Ceramics, Computing and Telecommunications, Analytical Chemistry. Environmental Science, Data Systems Research Development and Engineering Technology Division.

\section{Educational Activities:}

Project SEED students participated in their research during regular laboratory hours with a scheduled three hour seminar each Friday afternoon. The format of this program included guest speakers from different areas of research al Oak Ridge National Laboratory as well as information concerning careers in Science.

Tours of selected laboratory research facilities were conducted as part of the orientation program during the student's first week. The tours included information regarding the specific types of research conducted in the division being visited.

\section{Career Guidance:}

Career information was presented during the Friday seminars and included the material provided by the American Chemical Society along with talks given by the Oak Ridge National Laboratory Research staff.

\section{Communications Skills Development:}

Each participant was required to prepare a technical summary of their summer experience. Technical paper writing instructions were provided and each students completed this requirement. Oral presentations were required and were attended by the cooperating research mentors.

\section{Site Visits:}

To monitor the student's progress, students and their mentors were visited in the laboratory assignment by a summer high school mathematics teacher assigned to that task. Communications during the student's assignment was frequent and positive. 
Franklin A. Carrero Martiriez

Chemical Technology Division

Irvin W. Osborne-Lee

Waste Minimization (MN) is a policy specifically mandated by the United States Congress by the 1984 Hazardous and Solid Wastes Amendiments to the Resource Conservation and Recovery Act (RCRA). In the working definition currently used by the Environmental Protection Agency (EPA), a Waste Minimization Assessment (WMA) is a systematic planned procedure with the objective of identifying ways to eliminate or reduce waste.

Information is a vital element in waste minimization planning. The Waste Minimization Evaluation is a Planning tool that integrates and organizes data and methods used in planning and implementing a waste minimization activities. As an integral part of the WMES development, this task will links between waste minimization databases and input forms created using object-oriented software package (Object Vision). Using this software, a set of friendly forms will be created that will guide the user through different aspect of data access: data manipulation, updating records and/or files, creation of new data files, calculations, etc. Using this approach, would eliminate the need for users to learn a data base management system software.

Xiomara Carrero Martinez

Environmental Science Division

Pat Scarbrough

From the earliest civilizations to modern times, spatial data have been collected by navigators, geographers, and surveyors and rendered into pictorial form by cartographers. Originally maps were used to describe far-off places, as an aid to navigators and for military strategist. In present times maps are used and sometimes needed for many different purposes. That's why technology has developed systems that make it easier. one of those systems is the Geographic information System (GIS), A GIS is a computer system capable of assembling, storing, manipulating and displaying geographically referenced information, data identfied according to their locations. Applications of a GIS include forest and military planning and agricultural and environmental management.

In the GIS laboratory al ORNL some GIS coverages of maps are stored on the GIS1 computer. These was no documentation of what coverages are available or what they consist of. Because a GIS database is typically very large, and trying to find some information would take too much time, that documentation would be very valuable for GIS library users. Therefore this assignment was to create a file for each coverage in the database that help people to determine the usefulness of the data. The descriptive files were created using the ARC/NFO commands. Then trensferred the data to Word Perfect and printed out and compiled into a booklet. To perform this 
work some knowledge about GIS and ARCANFO was requirzd. It was done working with on line tutorials.

\author{
Carylee Castro \\ Energy Division \\ John H. Sorensen \\ Barbara Vogt
}

Medical wastes are defined to include all the types of waste produce by hospitals, clinics, doctor's offices, and other medical and research facilities. These waste include infections, hazardous, radioactive, and other general wastes from these healthier and medical facilities.

Infections waste is a relatively small portion of medical waste, although a high level of concern regarding their management exists. The amount of infectious waste generated by medical facilities as a percentage of their total waste stream varies widely depending on the type of health-care facility, the definition of infectious waste used, and the standard operating procedures specified by it for designating and separation waste types. Most hospitals, however, designate about 15 percent of their waste as infectious.

The adequate management of medical waste first became a major focus of public attention when medical wastes with other debris washed ashore on the East coast in the Summer of 1988.

The US. Environmental Protection Agericy (EPA) reports that autoclaving (steam sterilization) is utilized nationally to treat most infectious medical waste.

Many states have developed new regulations to control these medical wastes.

Nearly 70 percent of the nation's hospital use on-site incinerators. Some are used only for pathological waste disposal; others are used for disposal of infectious and non infectious medical waste.

EPA is the agency with the most comprehensive authority to provide Federal leadership on the management of medical waste.

\title{
Mariel Eliza Colon \\ Environmental Sciences Division \\ Oliver West - Lyuan Liang
}

The Southem Clean Fuels coal gasification plant was located in Wilsonville, Alabama. At present, all buildings have been demolished, and large amount of petroleum was left in the soil as an aftermath. Now, some sort of action should be taken to clean-up this side. Therefore, the soil needs to be characterized and a decision should be made on the approach to take to accomplish this task. 
The use of perox/dation is being evaluated as a potential treatment for the contaminated soil. The effectiveness of peroxidation depends directly on the iron content of the soil. An analysis of iron content invelves processes which transfer rernovable free iron oxides, by means of chelating agents, buffers, and iron reducers, from the soil itself into solution. This solution is then evaluated for iron content by means of an Atomic Absorption Spectrophotometer. It was found that the soil contained sufticient amount of iron that would facilitate a peroxidation process.

Zaida Yadira Diaz Colon

Chemical Technology Division

Irvin Ostom

Waste Minimization (WM) is a policy specifically mandated by the United States Congress by the 1984 Hazardous and Solid Waste Amendments to the Resource Conservation and Recovery Act (RCRA). In the working currently used by the Environmental protection Agency (EPA), a Waste Minimization Assessment (WMA) is a systematic planned procedure with the objective of identifying ways to eliminate or reduce waste.

Information is a vital element in waste minimization planning. The Waste Minimization Evaluation (WMES) is a planning tool that integrates and organizes data and methods used in planning and implementing waste minimization activities. As an integral part of the WMSE development, this task will develop databases with information that needed to support waste minimization planning and implementation. The development effort will require the gathering of information, data base structure design, and analysis using the data bases developed. This work will enable vital information to be conveniently accessed, making waste minimization activities such as process waste assessment much easier.

Mary Ariene Figueroa Sanchez Engineering Technology Division Joe P. Cunningham

Leamed how to manufacture optical components and surfaces using precision machining or diamond turning technology. By precision machining, we mean the combination of either single-point or multipoint diamond cutting tools and precision machines whose tool path accuracies range from a few microinches. The machined surface finishes achieved by this technique are generally of optical quality at infrared wavelengths and nearly so al visible wavelengths. Until this technology was developed, the only practical technique for generating optical surfaces had been loose abrasive grinding followed by polishing using slurries of various metal oxide powder. 
The selection and development of manufacturing processes for accurate optical surfaces must be concerned with how resultant optical surface interacts with characteristic of the incident radiation. Many optical properties affect this optical performance. All must be considered in the optical design and subsequent system's integration. If correctly executed, this design will reduce manufacturing to controlling only those parameters that directly impact optical performances. The problem of optical manufacturing, then, is normally reduced to one of controlling the two principal optical surface shape factors: contour and microtopography.

Jane Ely Lebron Santana

Chemical Technology Division

Brendly D. Faison

Considerable attention has been foclised on the environmental restoration of contaminated areas with metais. This research project will work in the development of a new biological technology for mobilization of these metal contaminates. The objective is to control the mobilization of metal within soil by binding it to stable compounds. The name of that compounds is pyoverdine and is produced in situ by endogenous populations of tluorescent Pseudomonas.

This particular project will focus on the identification and mapping of fiuorescent Pseudomonas within the soil, evaluating their localization considering factors like depth, vegetation, redox potential, moisture, and $\mathrm{pH}$. This work will be carried out in uncontaminated soils of West Knoxville.

Dianne M. Marquez Minondo

Chemistry Division

Elijah Johnson

In this project, the molecular dynamics method of classical statical mechanics is used in order to analyze and/or determine properties of ions in water, specifically the sodium ion ( $\mathrm{Na}+$ ) and the chloride ion (Cl-) in water. The objective is to determine how many water molecules surround each ion (coordination numbers) and the relative distance between ions in the solution (ionic association constants).

Scientists heve been trying to answer this question, but the results were always different, so they can't give accurate answers. The goal of this project is to find the way to solve this problem. 
Cynthia Enid Matos

Metals and Ceramics Division

Dane Wilson - Peter Tortorelfi

Corrosion is a serious problem and it definitely contributes to the depletion of our natural resources. Proper selection of materials and good design reduce the costs of corrosion. This task will investigate the behavior of developmental types of high strength 310 stainiess steel al high temperatures in oxygen-containment atmospheres. Both cyclic and isothermal oxidation behavior of these alloys will be studied. Optical and scanning electron microscopy will used to characterize the materials and to relate the oxidation products to the observad kinetics of formation. The oxidation resistance characteristics of these materials will be used as a guide for further developpent of this class of material.

\section{Brenda Rolon \\ Environmental Sciences Division \\ Brenda Thompson}

The Groundwater Section of the Environmental Sciences Division ai the ORNL must be keep updated information on all groundwater aspects - strike and dip measurements for the Oak Ridge Reservation geology have recently been changed. The original strike and dip coverage was digitized in 1992. It was checked and verified and it was found that there were some missing values or missing stations.

To make the coverage complete it was necessary to identify all the missing stations, then digitize them and create a strike and dip marker set to calculate the proper angle of each measurement. Merging SAS data into INFO and combining the original strike and dip coverage with the missing stations to create one master coverage will be the next steps in order to prepare full sized maps of the strike and dip coverage, and other full sized maps of strike and dip coverage and their base layers.

Daniel Sala Ortiz

Engineering Technology Division

Sherrell R. Greene - Juan Carbajo

Computer simulation is the primary means for understanding severe accidents in nuclear reactors. This simulations is normally provided by large, complex computer codes which model the various physical processes (heat transfer, fluid flow, fission product transport, etc.) occurring within the reactors and it's surrounding containment during the course of the accidents. The quality of the answer obtained with these codes are, of course, no better than the quality of the codes themselves and the input data provided to the codes. ORNL is currently involved in the analysis of a variety of 
hypothetical accidents in operating nuclear plants, as well as a variety of computer code assessment exercises in which predictions from computer codes are compared to those actually observed in experiments.

Michelaldemar Santiago Sanchez

Chemistry Division

Elijah Johnson

For a long time scientists have been studying the thermodynamics functions in a specific system. A water mixture of water and methanol will be used to obtain and to determine the thermodynamics functions from Molecular Dynamics method. This approach allow to find with precision; properties such as pair distribution funiction, Helmhotz free energy, pressure, and the energy of a water mixture. The energy and the pressure are found by using the trajectory of the position and momenta of the Sonyaparticules. A FORTRAN language program was created, in which physical properties and parameters for each system were set, in order to develop the research with accurate results.

\section{Sonya Brooks}

Office of Environmental Technoiogy Development

J.G. Pruett

Through The exploration of the new technologies that are currently being developed within the MMES complex, one would become exposed to a broad spectrum of environmental activities. The Office of Environmental Technology Development (OETD) commands a vast majority of the hazardous waste clean up activities. One would become familiar with establish of the Technology Development program as well the many objectives the program proposes to accomplish. A more definite understanding of the various components of the program such as waste minimization and avoidance, infrastructure, and program management, will be obtained from working within the office division. Becoming familiar with current technologies such as characterization and bioremediation through the exposure to the Technical Task Plans (TTPs) avaible for the fiscal year 1994 will access a more diverse field of experience. Using the available TTP files, one could integrate a variety of interest and skill such as processing a database management system. There is a broed range of area to discover by working within OETD, most of which evolves around one principal activity: The official documented plan that determines the overall technology development work- TTP! 


\section{Eva M. Crowe}

Data Systems Research \& Development

Ron Cain - Brian Ray

Integrated Computer Aided Software Englneering (ICASE) tools that support Information Engineering (IE) are considered to be a fundamental tool of software systerns development, which provides ccmprehensive documentation through each of the phases of system development. The Central Waste Tracking System (CWTS) utilized IE methods to develop Phase I of this system and these tools will also be utilized for planning and development of future phases. The iE methodology will be used to determine user requircmente and each phase, and will include user participation to arrive al a standard definition of the proposed system. The automated ICASE topl Information Engineering Facility (IEF) will be used throughout the development to document the user's business rules and user interface presentation.

Paper records present various problems for an urganization: a larye storage space, inability to quickly locate information needed, and susceptibility to fire, vandalism and theft. Converting information recorded on paper into an electronic form at solves all of the above problems. This project will be concomed with the concepts and practical applications of computar scanning and optical character recognition. The technical aspect of scanning such as document preparation and adjustment of scan parameters will bc introduced first. Once the documents have been scanned, character recognition software will be used to con'vert the graphic images into ASCII format. Finally, this data will be imported into a Relational Database Management System (RDBMS).

Dustin H. Harris

Engineering Technology Division

M. Alfreu Akerman

Various materials are used as components in composite armor. The influence of strength, models, the weight per unit, specific gravity, the weave, hardness, compressive strength, shape, and the fabrication process all relate to how successful an armor will be.

Balletic shielding, in its hard armor form, may be used for police barricades. SWAT team ballistic shields, and is used widely by the military. in this testing it was used to help alleviate the effects of an explosion In an airplane. 
Denley W. Hensley

Office of Environmental Technology Development

J. G. Pruett

In order to restore the environmentai to its original state, there must te certain guidelinas set as to how the problem will be handle and how much it shouid cost. That is the reason the OETD was created. From this division comes the money and go anead on research projects. There is a strict guide as to how these project are started. This paper will exempity the levels of acceptance of a research project and the process by which a TTP (Technical Task Flan) is developed and approved or denied. This will also show some of the major accomplishments of the $X .10$ staff in the fields of Waste and Environmental Restoration.

Kerry Ivey

Data Systems Research \& Development

Lea Martellaro

The training programs offered at Data Systems Research and Development are designed to provide necessary instruction to employees for corporate development and maximum job performance. It is mandatory that employees are given the opportunity to take all training required, therefore, communication is essential. This paper will explain one process of differentiating the expectations of management versus the views of the employees in respect to required education.

\section{Paige Zeigler}

Data Systems Research \& Development

Marge Elrod

The Pond Waste Management Project inventory Management Information System (PWMP-IMIS) is a information system designed to support environmental and waste operations. The PWMP-IMIS was also developed to accommodate remote data collection at U.S. Department of Energy (DOE) Oak Ridge K-25 Site. The mission of PWMP-IMIS is to correct the regulatory non-compliances associated with the handling of low-level waste currently held in approximately 78,000 drums and two 15,000 gallon Sludge LLP Atreatment Facility storage tanks at the K-25 Site.

The K-25 LLP (Landlord Program) is a program which manages the general use of facility and equipment projects for the K-25 Site Manager. The type of projects undertaken range from vehicle replacement, to electrical upgrade of buildings; to the construction of a new laundry facility. The K-25 LLP Document Management System is an information system designed to support the K-25 Landlord Program in the management and control of its program and project documentation. This system is being developed as one part of the K-25 LLP Management Information System. This 


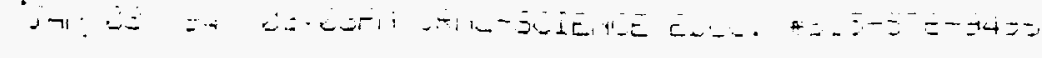

Jocumentation Management System will eventually contain data on 200 LLP projects. 


\section{PLANS FOR THE CONDUCT OF THE PROJECT, YEAR $6 / 8 / 9 d-6 / 7 / 95$}




\section{PLANS FOR CONDUCT OF THE \\ 1994 DOE Project SEED \\ Student Scholars Partnership}

\section{Overview}

The American Chemical Society (ACS) requests support for the final year of a five-year program involving 100 high-potential, economically disadvantaged, minority high school students at the Department of Energy National Laboratories and their associated institutions.

The program, to be run in cooperation with the highly-praised ACS Project SEED program, will consist of eight-week summer research projects at Oak Ridge National Laboratories and nine-week summer research projects at Los Alamos National Laboratories. Students will receive grants during 1994 of $\$ 1720$ for their participation and a small per diem to defray lunch and transportation costs.

The ACS will assist with student selection and will provide students with career guidance materials an other publications and services to promote their entry into science, mathematics, and engineering careers.

Following the summer program, the Society, working through ACS local sections in which programs are conducted, will organize a recognition program for students, chemistry teachers, and DOE mentor/researchers. The Society will also assess the value of this experience using a survey instrument developed by ACS Statistical Services. The results of the Student Scholars Partnership program will be disseminated widely using established ACS networks. 


\section{Project Narrative}

\section{Project Goals and Objectives}

The American Chemical Society is requesting funding for the final year of a five-year grant from the Department of Energy to support 20 high-potential, economically disadvantaged, minority, high school students in a scientific research project each summer at the Department of Energy (DOE) labs and their affiliated institutions. A total of 100 students will be involved over the five-year period.

This program relies heavily on the resources, networks, and experience gained by the ACS over the past 25 years through Project SEED, a summer science and career education program which has provided more nearly 4,000 high school student with the opportunity to participate in chemical research. Through its network of 186 lgcal sections and 240 SEED mentors, the ACS will assist the DOE labs to identify qualified students. Priority in the selection will be given to those students whose family incomes fall within Federal Poverty Income Guidelines.

The primary objectives of the DOE/Project SEED program are:

- to encourage economically disadvantaged high school students to enter scientific careers, and

- to provide a comprehensive experience in scientific research that will involve them in scientific methods and personal relationship with a mentoriresearcher.

Work Plan

Students in the DOE/Project SEED Student Scholars Partnership program will be involved in eight weeks of scientific methodologies and scientific philosophy. The ACS will provide materials to enhance their career awareness and planning. Both students and mentors will be recognized by their ACS local section.

The students will be given a research grant of $\$ 1720$ for the summer. An average of $\$ 10.26$ per day will also be made available to students with additional financial need to defray the cost of transportation and lunch. By making available grant funds that approximate what a student might otherwise earn at a typical summer job, we hope to attract in particular those young people who are economically disadvantaged and for whom a summer job provides a critical source of income.

ACS-supported follow-up will include a one-year membership in the ACS Student Affiliates program for those student majoring in chemistry; one-year subscription to CHEMMATTERS (the ACS magazine for high school students); suitable certificates to be presented by the ACS local sections; and, introductions to chemists in the student's communities (through the local sections) who can serve as role models and help give the students professional support. Each student will also participate in an ongoing evaluation of their career plans and progress. This survey will be conducted by Project SEED with assistance from ACS Statistical Services. 


\section{Procedures}

The ACS will assist the DOE mentors to recruit students by providing sample letters, forms, names (where possible) and addresses for local high school personnel (principals, guidance counselors, and teacher). The mentor/researchers will be asked to follow up on applicants by calling the high schools and evaluating the applications received. Eligible students will be minority high school students. Preference will be given to students from low-income families. Students will be selected based on grade-point average, standardized test scores (if available), and teacher recommendations. Mentors will interview the most likely candidates. All students will have completed 10 th or 11 th grade and have had a year of chemistry.

\section{Project Staff}

The coordination of all activities relating to this project that involves AGS in Washington, DC (career workshop planning, subscription and award coordination, and student surveys and evaluations) will be the responsibility of Dr. Christine Berg Brennan, Senior Staff Associate in the ACS Office of High School Chemistry. She will write the final project report to the Department of Energy and make certain that the results of this partnership are widely disseminated in the science and education communities.

Because of its extensive national network, the ACS is uniquely qualified to coordinate the program at the DOE sites, supply all students with relevant and exciting career and science education materials, and assist with successful career counseling activities for the participating students. ACS Statistical Services can provide a broad base of evaluation support and help compare the achievement of the DOE/Project SEED students with that of student involved in the parallel, though less comprehensive, Project SEED program.

\section{Project Facilities}

While project coordination and administration will take place in the ACS Office of High School Chemistry in Washington, DC, the student research will take place at DOE National Laboratories and their associated academic and industrial institutions. Two of the DOE national laboratories (Oak Ridge and Los Alamos) have previously hosted Project SEED students and have reported positive experiences.

\section{Project Outcomes}

Many of the students in the ACS Project SEED program contribute to the research that is published by their mentor. Even though publication in a peerreviewed journal is an endorsement of the quality of the research conducted, it is certainly not an indication of the value of the program to the student involved. The real success of the DOE/Project SEED program must depend on the extent to which each student participant feels that he or she has benefited from the summer. This judgment is often difficult to make at the time. To evaluate the success of the program, we will use a multi-year survey instrument developed by ACS Statistical Services that is parallel in format to the evaluation completed by the Project SEED students participating in a longitudinal study. 
This project will involve as partners the Department of Energy and its laboratories, the American Chemical Society, ACS local sections, and the high school connected with each student. This model partnership program will be publicized through various ACS journals and newsletters, including the Journal of Chemical Education and Chemunity News (a newsletter for elementary, high school, and college chemistry teachers).

Personnel

Christine Berg Brennan will serve as the project director and Raihanah A. Rushed (Renee J. Strong) will continue as staff assistant.

Budget Removed at 